\title{
Effect of respiratory therapy on pulmonary functions in children with cerebral palsy: a systematic review
}

\author{
Eman H. El Banna* (D), Eman I. El Hadidy and Walaa M. Ali
}

\begin{abstract}
Background: Children with cerebral palsy (CP) are at risk for respiratory dysfunction. Early initiation of pulmonary rehabilitation in addition to conventional physical therapy may result in improvement and maintenance of chest mobility and respiratory function. However, empirical support for respiratory therapy is limited. The aim of the review was to assess the evidence of the effectiveness of respiratory therapy on pulmonary functions in children with CP.

Methods: Four electronic databases (PubMed, Cochrane Library, Physiotherapy Evidence Database (PEDro), and Google Scholar) were searched till December 2019 using predefined terms by two independent reviewers. Randomized controlled trials published in English were included if they met the following criteria: population -children with different types of CP of both sex, aged up to 18 years; intervention — respiratory therapy; outcomes - pulmonary functions. Eight studies with 235 participants only met the inclusion criteria and were included in this review. Predefined data were tabulated using American Academy for Cerebral Palsy and Developmental Medicine by two reviewers and verified by a third reviewer. Methodological quality was assessed using rating system of quality assessment and PEDro scale; also, levels of evidence adopted from modified Sacket's scale were used for each outcome.
\end{abstract}

Results: The quality of studies ranged from excellent (one study) to good (five studies) and fair (two studies). The results showed level 1 (six studies) and level 2 (two studies) on modified Sacket's scale for level of evidence. Lack of allocation concealment and blinding was the major risk of bias in the included studies.

Conclusions: Meta-analysis revealed significant difference in the improvement of vital capacity, peak expiratory flow, and forced expiratory volume at $1 \mathrm{~s}$ in favor of the study groups. However, there is a need for high-quality studies to draw a clear conclusion.

Keywords: Cerebral palsy, Respiratory therapy, Pulmonary functions, Systematic review, Children

\section{Background}

Cerebral palsy $(\mathrm{CP})$ is a group of disorders affecting body movement and muscle coordination caused by damage to one or more areas of the brain, usually occurring during fetal development or infancy [1]. It is the most common cause of long-term childhood disability, affecting 2.1 per 1000 live births [2].

\footnotetext{
*Correspondence: emanpt@yahoo.com

Department of Physical Therapy for Pediatrics, Faculty of Physical Therapy, Cairo University, Giza, Egypt
}

\section{Springer Open}

Respiratory problems in children with $\mathrm{CP}$ are always related to reduced chest wall mobility and insufficient respiratory muscle strength which results in ineffective alveolar ventilation, poor airway clearance, and shortness of breath. These factors lead to repeated hospital admission due to increased risk of developing atelectasis, pneumonia, or chronic respiratory failure [3-5].

Although CP is not itself a respiratory disease, application of interventions that improve respiratory health is one of the most important factors in promoting the

(c) The Author(s). 2020 Open Access This article is licensed under a Creative Commons Attribution 4.0 International License, which permits use, sharing, adaptation, distribution and reproduction in any medium or format, as long as you give appropriate credit to the original author(s) and the source, provide a link to the Creative Commons licence, and indicate if changes were made. The images or other third party material in this article are included in the article's Creative Commons licence, unless indicated otherwise in a credit line to the material. If material is not included in the article's Creative Commons licence and your intended use is not permitted by statutory regulation or exceeds the permitted use, you will need to obtain permission directly from the copyright holder. To view a copy of this licence, visit http://creativecommons.org/licenses/by/4.0/. 
quality of life for these children and their families. Also, it minimizes the health care costs associated with CP [6].

Respiratory therapy is a group of techniques designed to enhance functional residual capacity and provide greater alveolar stability. It may be applied with or without mechanical devices [7]. It includes the removal of excess bronchial secretions and maintaining and improving exercise capacity. Physical therapy can support ventilation by using high-flow nasal cannulas, continuous positive airway pressure or noninvasive ventilation, and postural education. Also, it prevents, corrects, and improves postural problems, such as kyphosis where poor posture leads to tightening of the respiratory muscles and chest wall deformity and augments the decline in pulmonary functions [8].

Respiratory muscle strengthening has shown a significant association with indicators of health fitness (heart and respiratory rates) and daily functional ability in children with CP [9]. Previous study had reported that feedback respiratory training (FRT) can improve respiratory function, endurance for exercise capacity, sense of dyspnea, and quality of life [10]. Interventions based on therapeutic exercises have been shown a positive effect on social life, self-esteem, depression, and self-confidence in terms of involvement in physical activities [11].

Current evidence regarding management of children with $\mathrm{CP}$ who are at risk of developing respiratory disease is very limited [12].The purpose of this study was to systematically review the quality of evidence regarding the effectiveness of respiratory therapy on pulmonary functions in children with $\mathrm{CP}$.

\section{Methods}

Two reviewers performed an electronic search up to December 2019. The following databases were searched to identify relevant published studies: the Cochrane Library, Physiotherapy Evidence Database (PEDro), PubMed, and Google Scholar. Those databases were searched by using the following keywords: "Cerebral palsy", "Respiratory therapy", "respiratory muscle training", and "incentive spirometer", "chest physiotherapy", "breathing exercises", "pulmonary functions". All articles that were considered potentially eligible were obtained in full text, and additional screening of reference lists of the eligible studies was also performed.

\section{Eligibility criteria}

Studies were considered eligible if they satisfied the following criteria:

- Participants: children with different types of $\mathrm{CP}$ of both sex aged up to 18 years old.

- Study design: only randomized controlled trials (RCT).

- Type of intervention: respiratory therapy in form of incentive spirometry, respiratory exercises (breathing exercises, diaphragmatic breathing, thoracic expansion exercises), respiratory muscle training (using pressure threshold-loading device and training apparatus with different valves), and exercise training programs (task-specific movement exercise and aquatic exercise).

- Outcomes: pulmonary functions including vital capacity (VC), forced vital capacity (FVC), forced expiratory volume at $1 \mathrm{~s}\left(\mathrm{FEV}_{1}\right)$, expiratory reserve volume (ERV), peak expiratory flow (PEF), forced expiratory flow (FEF), tidal volume (TV), and inspiratory reserve volume (IRV).

- Language: full-text papers in English.

\section{Exclusion criteria}

- Unpublished studies

- Study design other than RCT such as review papers, case reports, observational studies, and conference proceedings

- Studies that measured outcomes not related to the scope of our study such as cardiovascular parameters, anaerobic threshold, and use of antibiotic therapy

\section{Data extraction}

Two authors used the data extraction form developed by the American Academy for Cerebral Palsy and Developmental Medicine (AACPDM) [13] to extract data which include the following items: (a) the author and year of publication; (b) information on the population, describing numbers of included children by diagnosis, and age; (c) study design; (d) methodology, including the type of intervention or assessment, technique of its application, and its duration; (e) measured outcomes; and (f) results. The AACPDM's ratings of evidence and study quality for group design studies have acceptable inter-rater reliability and convergent validity when compared with a similar tool [14].

\section{Assessment of methodological quality}

Methodological quality in the current systematic review was evaluated by using the AACPDM rating system of quality assessment [13] and the PEDro scale. PEDro is a valid measurement of methodological quality of clinical trials [15]. The internal validity of the included studies was assessed through PEDro scale criteria of adequate randomization; allocation concealment; blinding of participants, therapists, and research personnel; incomplete outcome data; baseline similarity; and use of intention to treat analysis. The items are scored as present (1) or absent (0). Two reviewers independently assessed the methodological quality of included studies, and discrepancies between them were resolved by consultation with the third author to reach the final decision. After each item was classified as "present" or "absent," the total score of each study was calculated as the sum of "present" responses. Scores range from 0 to 10 with higher scores indicating a better methodological quality of the RCT. The quality of the 
individual study would be judged as excellent (score 9-10), good (score 6-8), fair (score 4-5), and poor (score < 3) [16].

While the AACPDM conduct questions consist of clear eligibility criteria, reliable outcome measures, blinding assessors, power calculations, and controlling other sources of bias (such as insufficient follow-up, unclear type of random sequence generation or allocation concealment, lack of intention to treat). Each question should be answered "yes" (criterion/criteria present) or "no" (criterion/criteria not present). For group studies, the quality of the individual study would be judged as strong ("yes" score on 6-7 of the questions), moderate (score 4 or 5$)$, or weak (score $<3$ ).

\section{Level of evidence}

The level of evidence of all included studies was scored according to the modified Sackett scale [17] (Table 1). This five-level scale was used to determine the strength of evidence regarding the intervention.

\section{Data analysis}

Data were summarized statistically if two or more published studies were comparable in terms of intervention, patient demographics, outcome measures, and adequate quality. The data were pooled for meta-analysis using Review Manager (RevMan-version 5.4). The variables used in the metaanalysis were $\mathrm{VC}, \mathrm{PEF}, \mathrm{FEV}_{1}, \mathrm{FEV}_{1} / \mathrm{FVC}$, and FVC. We expressed pooled continuous measures as the mean difference (MD) with 95\% CI. We explored and quantified between-study statistical heterogeneity using the $I^{2}$ test. By default, we used the fixed effect model in all analyses. If heterogeneity was statistically significant $(p<0.05)$ or $I^{2}$ was > $50 \%$, we used random-effects model instead.

\section{Results}

\section{Literature search}

The search strategy revealed 2189 articles from previously mentioned databases, as follows: Cochrane Library (130), PEDro (23), PubMed (79), and Google scholar (1957). Duplicated articles were 1239. The reviewers screened titles and abstracts of the remaining 950 articles independently. Seventy articles were filtered on the basis of full-text; sixty-two were excluded because they were outside the scope, because the children's diagnosis was not $\mathrm{CP}$, or outcome of interest was absent, as shown in the Preferred Reporting Items for Systematic Reviews and Meta-Analyses flow chart (PRISMA) (Fig. 1) [18]. The remaining 8 studies formed the basis for the current systematic review.

\section{Characteristics of the studies}

There was some homogeneity among included studies regarding general characteristics of participants, outcome measures, and assessment methods (Table 2). So these studies underwent meta-analysis.

\section{Characteristics of participants}

Two hundred thirty-five children ranged from 5 to 15 years of age were diagnosed with diplegic [19-22, 24], hemiplegic [20-22, 24], quadriplegic [20, 22, 26], and triplegic [22] CP of different levels of severity. Two studies did not specify CP type $[23,25]$.

\section{Intervention}

All studies examined the effect of different types of respiratory therapy (breathing exercises [19], aquatic activities [20], feedback respiratory muscle training [21], incentive spirometer [22], upper extremity resistance exercise [23], inspiratory muscle training at 30\% MIP [24], task-specific movement exercise with loaded resistance [25], and respiratory exercises [26]).

\section{Comparators}

Six studies applied conventional physical therapy in the form of neurodevelopmental technique [19-23, 26]. One study used inspiratory muscle training at 5\% MIP and home program [24]. Other study applied ROM and stretching exercises [25]

Table 1 Modified Sackett scale

\begin{tabular}{ll}
\hline Level & Study design \\
\hline 1 & RCT (PEDro score $\geqslant 6$ ) \\
2 & RCT (PEDro score $<6$ ), prospective controlled trial, cohort \\
3 & Case control \\
4 & One-group pretest-posttest, case series \\
5 & Case report \\
\hline
\end{tabular}

Abbreviations: PEDro, Physiotherapy Evidence Database; RCT, randomized controlled trials. 


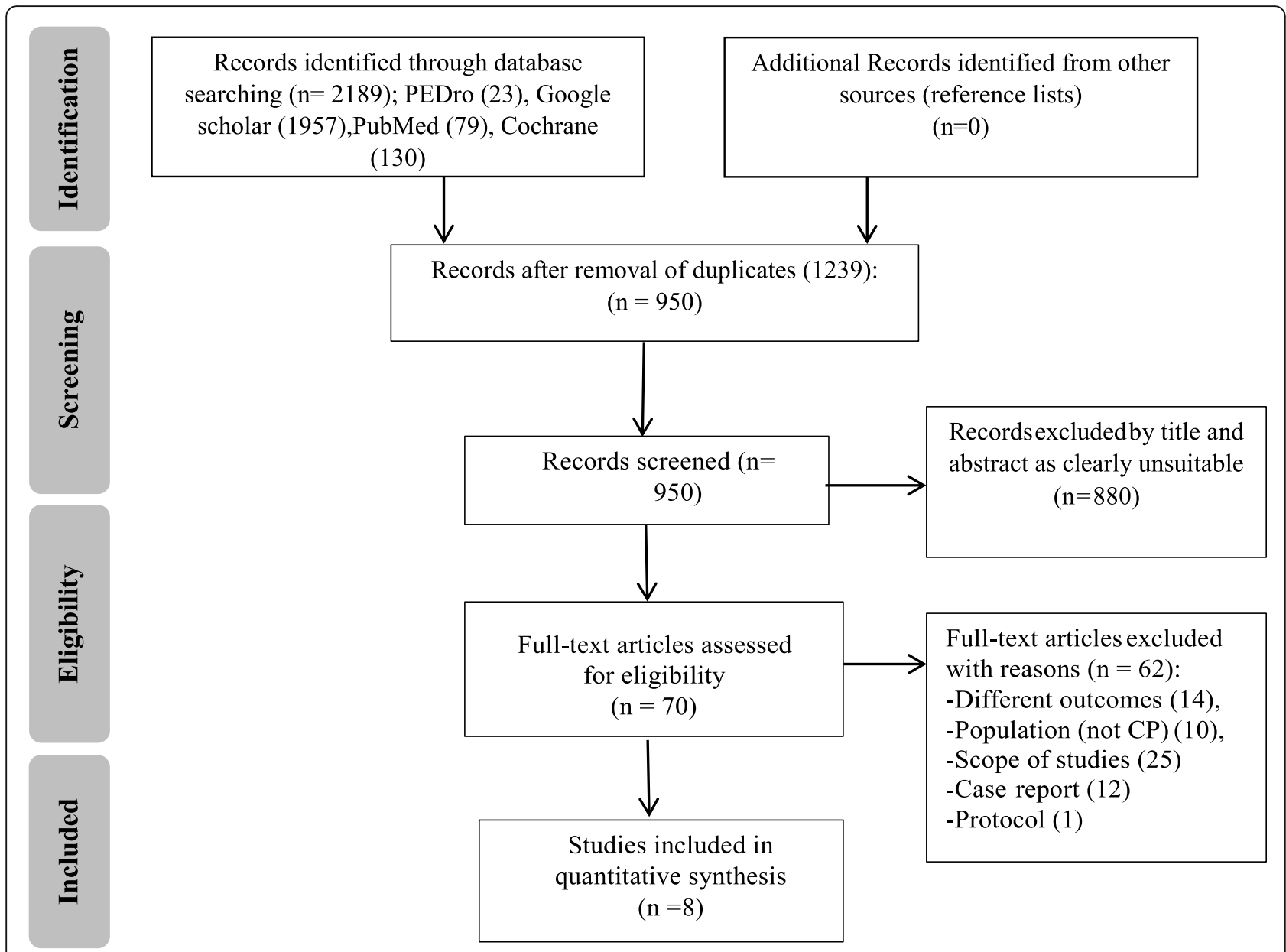

Fig. 1 PRISMA (Preferred Reporting Items for Systematic Reviews and Meta-Analyses) flowchart

\section{Types of outcome measured}

Pulmonary functions measured are VC [19-21], FVC [21-26], FEV 1 [19, 21-26], PEF [21-26], $\mathrm{FEV}_{1} / \mathrm{FVC}$ ratio [22, 26], FEF [24], ERV, TV, and IRV [21].

\section{Measurement of pulmonary functions}

All studies used spirometer for measuring pulmonary functions.

\section{Level of methodological quality}

The score of each study on the PEDro scale is presented in Table 3. The mean score of the 8 studies was 6.5. One study obtained a score of 9 [24] which represents "excellent" quality, two studies had a score of 8 [21, 25], and three studies scored $6[19,20,23]$ which represent "good" quality. One study was given a score of 5 [22], and one study was given score of 4 [26] which represent "fair" quality.

The score of each study on the AACPDM conduct questions is also presented in Table 4. The mean score of the 8 studies was 4.75 . One study obtained a score of 6 [24] which represents "strong" quality. Five studies had a score of $5[20-22,25,26]$, and one study obtained a score of 4 [23] which represent "moderate" quality, and one study obtained a score of 3 [19] which represents "weak" quality.

\section{Level of evidence}

According to the modified Sackett scale, six studies [19$21,23-25$ ] were ranked on level one, and two studies were on level two $[22,26]$ as presented in Table 4.

\section{Descriptive synthesis of the risk of bias}

Most studies had participants allocated randomly, had groups of similar baselines, reported results of betweengroup statistical comparisons, provided measures of variability for at least one outcome, and specified the eligibility criteria. Only two studies [21, 24] had concealed allocation and blinded assessors; three studies [21, 24, 25] had blinded participant, two of them [24, 25] had blinded therapist. 
Table 2 Participant, diagnosis, intervention, comparators, duration, outcome measures, results

\begin{tabular}{|c|c|c|c|c|c|c|c|}
\hline Study & Participant & Diagnosis & Intervention & Comparators & Duration & $\begin{array}{l}\text { Outcome } \\
\text { measures }\end{array}$ & Results \\
\hline $\begin{array}{l}\text { 1- } \\
\text { Rothman } \\
{[19]}\end{array}$ & $\begin{array}{l}N=10 \\
\text { (Exp. gp = } \\
5, \text { Cont.gp } \\
=5 \text { ) } \\
\text { Age (years) } \\
5-9\end{array}$ & $\begin{array}{l}\text { Spastic } \\
\text { diaplegic CP } \\
\text { children }\end{array}$ & $\begin{array}{l}\text { Breathing exercises 5-7 } \\
\text { min/day }\end{array}$ & $\begin{array}{l}\text { Bobath treatment } \\
\text { approach }\end{array}$ & 8 weeks & $\begin{array}{l}\mathrm{VC} \\
\mathrm{FEV}_{1}\end{array}$ & $\begin{array}{l}\text {-Significant improvement of } \\
\text { VC mean }=0.46 \mathrm{~L} \text { at } p= \\
0.005 \\
\text {-Both groups showed no } \\
\text { significant difference in the } \\
\text { pretest and posttest values }\end{array}$ \\
\hline $\begin{array}{l}\text { 2-Hutzler } \\
\text { et al. [20] }\end{array}$ & $\begin{array}{l}N=46 \\
\text { (Exp.gp }= \\
23, \text { cont.gp } \\
=23 \text { ) } \\
\text { Age (years) } \\
5-7\end{array}$ & $\begin{array}{l}\text { Spastic } \\
\text { diaplegic, } \\
\text { hemiplegia, } \\
\text { quadriplegia, } \\
\text { and ataxic } \\
\text { CP children }\end{array}$ & $\begin{array}{l}\text { Swimming session twice } \\
\text { weekly + group physical } \\
\text { activity once weekly ( } 30 \\
\text { min duration) }\end{array}$ & $\begin{array}{l}\text { Bobath physical therapy } \\
\text { (4 day/week; } 30 \text { min } \\
\text { duration) }\end{array}$ & 6 months & $\begin{array}{l}\text { VC } \\
\text { WOS }\end{array}$ & $\begin{array}{l}\text {-Significant increase in } \\
\text { mean value of } \mathrm{VC}=35.8 \text { at } \\
p=0.009 . \\
\text {-Significant increase in raw } \\
\text { scores of WOS with mean } \\
\text { value }=33.4 \text { at } p<0.001\end{array}$ \\
\hline $\begin{array}{l}\text { 3-Lee et al. } \\
\text { [21] }\end{array}$ & $\begin{array}{l}N=22 \\
\text { (Exp.gp }= \\
11, \text { cont.gp } \\
=11 \text { ) } \\
\text { Age (years) } \\
6-12\end{array}$ & $\begin{array}{l}\text { Spastic } \\
\text { diaplegic, } \\
\text { hemiplegic } \\
\text { CP children }\end{array}$ & $\begin{array}{l}\text { Feedback respiratory } \\
\text { training }(15 \mathrm{~min})+ \\
\text { conventional } \\
\text { rehabilitation ( } 30 \mathrm{~min}) \\
\text { with } 10 \text { min break in } \\
\text { between } 3 \text { days/week }\end{array}$ & $\begin{array}{l}\text { CPT (gross motor } \\
\text { activities) } 20 \text { min, } 3 \\
\text { days/ week }\end{array}$ & 4 weeks & $\begin{array}{l}\text { Pulmonary } \\
\text { functions } \\
\text { (FVC, FEV } 1 \\
\text { PEF, VC, ERV, } \\
\text { TV, IRV) }\end{array}$ & $\begin{array}{l}\text { The experimental group } \\
\text { showed significant increase } \\
\text { in } \mathrm{VC} \text { and } \mathrm{FEV}_{1} \text { mean } \\
\text { values }(1.5,1.4) \text { respectively } \\
\text { at } p<0.005 \text { with no } \\
\text { significant changes in other } \\
\text { measures. }\end{array}$ \\
\hline $\begin{array}{l}\text { 4-Choi } \\
\text { et al. [22] }\end{array}$ & $\begin{array}{l}N=50 \\
\text { (Exp.gp }= \\
25, \text { cont.gp } \\
=25 \text { ) } \\
\text { age (years) } \\
8-15\end{array}$ & $\begin{array}{l}\text { Spastic } \\
\text { diaplegic, } \\
\text { hemiplegic, } \\
\text { quadriplegic, } \\
\text { and triplegic } \\
\text { CP children }\end{array}$ & $\begin{array}{l}\text { ISE } 10-15 \text { breath/session } \\
10 \text { sessions daily + } \\
\text { conventional } \\
\text { rehabilitation + } \\
\text { occupational therapy }\end{array}$ & $\begin{array}{l}\text { CPT + occupational } \\
\text { therapy } 5 \text { times/week }\end{array}$ & 4 weeks & $\begin{array}{l}\text {-Pulmonary } \\
\text { functions } \\
\text { (FEV }, \text { FVC, } \\
\text { PEF, FEV } / \\
\text { FVC). } \\
\text {-GMF } \\
\text {-MPT }\end{array}$ & $\begin{array}{l}\text {-The experimental group } \\
\text { showed significant increase } \\
\text { in } \mathrm{FEV}_{1} \text { and } \mathrm{FVC} \text { mean } \\
\text { values }(1.57,2.15) \\
\text { respectively at } p<0.005 \text {. } \\
\text {-Both groups showed no } \\
\text { significant difference in the } \\
\text { pretest and posttest values } \\
\text { in GMF. } \\
\text {-Significant increase in MPT } \\
\text { mean value-12.13 at } p= \\
0.001\end{array}$ \\
\hline $\begin{array}{l}\text { 5-Shin and } \\
\text { Kim et al. } \\
{[23]}\end{array}$ & $\begin{array}{l}N=15 \\
\text { (Exp.gp = } \\
\text { 8, Cont.gp } \\
=7 \text { ) } \\
\text { Age } \\
\text { (mean): Exp } \\
\text { 9.25, } \\
\text { Con.gp } \\
9.57\end{array}$ & $\begin{array}{l}\text { Spastic CP } \\
\text { children }\end{array}$ & $\begin{array}{l}\text { Upper extremity } \\
\text { resistance exercise using } \\
\text { thera band ( } 20-30 \text { min/ } \\
\text { session) + NDT ( } 30 \text { min } 2 \\
\text { session/week) }\end{array}$ & $\begin{array}{l}\text { NDT ( } 30 \text { min } 2 \text { session/ } \\
\text { week) }\end{array}$ & 8 weeks & $\begin{array}{l}\text {-Pulmonary } \\
\text { functions } \\
\text { (FVC, FEV }{ }_{1} \\
\text { PEF) } \\
\text { - Respiratory } \\
\text { muscle } \\
\text { strength } \\
\text { (MIP, MEP) } \\
\text {-Grip } \\
\text { strength }\end{array}$ & $\begin{array}{l}\text {-Significant improvement in } \\
\text { FVC, FEV1, PEF, and MIP } \\
\text { with mean values } 0.09,0.17 \text {, } \\
0.46 \text {, and } 1.88 \text {, respectively } \\
\text { group with no statistical } \\
\text { difference between both } \\
\text { groups } \\
\text {-Grip strength and MEP } \\
\text { significantly improved in } \\
\text { Exp.gp with mean value } \\
(0.82,6) \text { respectively at } p< \\
0.005\end{array}$ \\
\hline $\begin{array}{l}\text { 6-Keles } \\
\text { et al. [24] }\end{array}$ & $\begin{array}{l}N=28 \\
\text { (Exp.gp }= \\
14, \text { Cont.gp } \\
=14 \text { ) } \\
\text { Age (years) } \\
7-14\end{array}$ & $\begin{array}{l}\text { Spastic } \\
\text { diaplegic, } \\
\text { hemiplegic } \\
\text { CP children }\end{array}$ & $\begin{array}{l}\text { Inspiratory muscle } \\
\text { training at } 30 \% \text { MIP } \\
\text { (twice daily; } 15 \text { min) + } \\
\text { CPT ( } 40 \text { min/day, } 3 \text { days/ } \\
\text { week) + home program } \\
\text { of breathing exercises }\end{array}$ & $\begin{array}{l}\text { Inspiratory muscle } \\
\text { training at } 5 \% \text { MIP (15 } \\
\text { min twice daily) + CPT } \\
(40 \text { min/day, } 3 \text { days/ } \\
\text { week }+ \text { home program } \\
\text { of breathing exercises }\end{array}$ & 6 weeks & $\begin{array}{l}\text {-Pulmonary } \\
\text { functions } \\
\text { (FEV }, \text { FVC, } \\
\text { FEF, PEF, } \\
\text { MIP, MIP\%, } \\
\text { MEP, MIP\%) } \\
\text {-Trunk } \\
\text { control } \\
\text {-Daily living } \\
\text { activities } \\
\text {-Functional } \\
\text { exercise } \\
\text { capacity } \\
\text {-Quality of } \\
\text { life }\end{array}$ & $\begin{array}{l}\text {-No significant difference in } \\
\text { pulmonary functions } \\
\text { between both groups } p> \\
0.005 \text {. } \\
\text {-Significant improvements } \\
\text { in MIP mean value }=28.66 \\
\text { at } p<0.001 \\
\text {-Significant improvement in } \\
\text { trunk control of study } \\
\text { group mean value = } 4.50 \text { ( } p \\
<0.001 \text { ) } \\
\text {-Significant improvement in } \\
\text { self-care }(2.28, p=0.007 \text { ), } \\
\text { mobility ( } 3.39, p=0.001) \text {, } \\
\text { and social function ( } 2.56 \text { ) } \\
\text { domains in study group } \\
\text { only and no significant dif- } \\
\text { ference bet. } 2 \text { groups in } \\
\text { other domains in PEDI-CAS } \\
\text { subscale scores } \\
\text {-Significant improvement in }\end{array}$ \\
\hline
\end{tabular}


Table 2 Participant, diagnosis, intervention, comparators, duration, outcome measures, results (Continued)

\begin{tabular}{|c|c|c|c|c|c|c|c|}
\hline Study & Participant & Diagnosis & Intervention & Comparators & Duration & $\begin{array}{l}\text { Outcome } \\
\text { measures }\end{array}$ & Results \\
\hline & & & & & & & $\begin{array}{l}\text { distance covered during } \\
6 \mathrm{MWT} \text { in study group only } \\
(66.38, p<0.001) \\
\text {-Significant improvement in } \\
\text { social well-being and ac- } \\
\text { ceptance }(10.44, p<0.001) \\
\text { and functioning domain } \\
(3.59, p=0.004) \text { scores in } \\
\text { study group only, no sig- } \\
\text { nificant difference bet. } \\
\text { groups in other domains of } \\
\text { CPQOL-Child }\end{array}$ \\
\hline $\begin{array}{l}\text { 7-Kwon } \\
\text { and Kim } \\
{[25]}\end{array}$ & $\begin{array}{l}N=34 \\
\text { (Exp.gp }= \\
17, \text { Cont.gp } \\
=17 \text { ) } \\
\text { Age (years) } \\
4-12\end{array}$ & $\begin{array}{l}\text { Spastic CP } \\
\text { children }\end{array}$ & $\begin{array}{l}\text { Task-specific movement } \\
\text { patterns with loaded } \\
\text { resistance ( } 40 \text { min twice/ } \\
\text { week) + ROM and } \\
\text { stretching exercise (5-10 } \\
\text { min) }\end{array}$ & $\begin{array}{l}\text { Task-specific movement } \\
\text { patterns without loaded } \\
\text { resistance }(40 \text { min } \\
\text { twice/week) + ROM and } \\
\text { stretching exercise (5- } \\
10 \text { min) }\end{array}$ & 12 weeks & $\begin{array}{l}\text {-Respiratory } \\
\text { functions } \\
\text { (FVC, FEV }{ }_{1} \\
\text { PEF) } \\
\text {-Thickness } \\
\text { of } \\
\text { abdominal } \\
\text { muscles }\end{array}$ & $\begin{array}{l}\text {-Significant improvement in } \\
\text { mean values of FVC }(1.72) \text {, } \\
\text { FEV } 1(1.69) \text {, PEF }(1.69) \text { at } p< \\
0.05 \text { in Exp. group } \\
\text {-Significant improvement in } \\
\text { abdominal muscle } \\
\text { thickness }(p<0.05) \text { in Exp. } \\
\text { group }\end{array}$ \\
\hline $\begin{array}{l}\text { 8-Kanna } \\
\text { and } \\
\text { Balabaskar } \\
{[26]}\end{array}$ & $\begin{array}{l}N=30 \\
\text { (Exp.gp }= \\
15, \text { Cont.gp } \\
=15) \\
\text { Age (years) } \\
6-14\end{array}$ & $\begin{array}{l}\text { Spastic } \\
\text { quadriplegic } \\
\text { CP children }\end{array}$ & $\begin{array}{l}\text { Respiratory exercises } \\
\text { along with NDT for } 45 \\
\text { min ( } 30 \text { min and } 15 \text { min), } \\
5 \text { days in a week }\end{array}$ & $\begin{array}{l}\text { NDT for } 45 \mathrm{~min}, 5 \text { days } \\
\text { in a week }\end{array}$ & 6 weeks & $\begin{array}{l}\text { Pulmonary } \\
\text { functions } \\
\text { (FVC, FEV } \\
\text { FEV }_{1} / F V C \\
\text { ratio } P E F \text { ) }\end{array}$ & $\begin{array}{l}\text { Significant improvement in } \\
\text { mean values of FVC }(1.65+ \\
0.98), \mathrm{FEV}_{1}(1.28+0.84), \mathrm{PEF} \\
(2.32+1.23) \text {, and } \mathrm{FEV}_{1} / \mathrm{FVC} \\
(80.63+16.80) \text { in } \\
\text { experimental group ( } p< \\
0.05)\end{array}$ \\
\hline
\end{tabular}

6MWT 6-minute walk test, Cont.gp Control group, CP Cerebral palsy, CPQOL Cerebral palsy quality of life, CPT Conventional physical therapy, ERV Expiratory reserve volume, Exp.gp Experimental group, FEF Forced expiratory flow, FEV 1 Forced expiratory volume at 1 s, FVC Forced vital capacity, GMFM Gross motor function measure, IRV Inspiratory reserve volume, ISE Incentive spirometry exercise, MEP Maximal expiratory pressure, MIP Maximal inspiratory pressure, $N$ Total number, NDT Neurodevelopmental treatment, PEDI-CAS Pediatric evaluation of disability inventory-caregiver assistance scale, $P E F$ Peak expiratory flow, ROM Range of motion, TV Tidal volume, VC Vital capacity

\section{Meta-analysis}

We performed a meta-analysis for five variables: VC (Fig. 2), PEF (Fig. 3), $\mathrm{FEV}_{1}$ (Fig. 4), $\mathrm{FEV}_{1} / \mathrm{FVC}$ ratio (Fig. 5), and FVC (Fig. 6).

\section{Measures of treatment effects}

The outcome variables of interest were continuous outcomes. Data of change scores of post-intervention measures were evaluated and entered as means and standard deviations (SDs), and the mean difference (MD) with 95\% confidence intervals (CIs) for each trial was calculated. Data were pooled through calculation of the overall MD and 95\% CI.

\section{Vital capacity}

Data for meta-analysis could be extracted from three studies [19-21]. As reflected from Fig. 2, the total number of children included into meta-analysis was 37 in study groups and 39 in control groups. The forest plot of mean difference across the three studies at $95 \% \mathrm{CI}$ of mean difference is MD

Table 3 PEDro scale

\begin{tabular}{|c|c|c|c|c|c|c|c|c|c|c|}
\hline Study & $\begin{array}{l}\text { Random } \\
\text { allocation of } \\
\text { subjects }\end{array}$ & $\begin{array}{l}\text { Concealed } \\
\text { allocation }\end{array}$ & $\begin{array}{c}\text { Similarity } \\
\text { at } \\
\text { baseline }\end{array}$ & $\begin{array}{l}\text { Blinded } \\
\text { subjects }\end{array}$ & $\begin{array}{l}\text { Blinded } \\
\text { therapists }\end{array}$ & $\begin{array}{r}\text { Blinded } \\
\text { assessors }\end{array}$ & $\begin{array}{l}\text { More than } \\
85 \% \text { follow- } \\
\text { up }\end{array}$ & $\begin{array}{l}\text { Intention-to- } \\
\text { treat } \\
\text { analysis }\end{array}$ & $\begin{array}{c}\text { Between-group } \\
\text { statistical } \\
\text { analysis }\end{array}$ & $\begin{array}{l}\text { Point and } \\
\text { variability } \\
\text { estimates }\end{array}$ \\
\hline 1-Rothman [19] & Yes & No & Yes & No & No & No & Yes & Yes & Yes & Yes \\
\hline 2-Hutzler ef al. & Yes & No & Yes & No & No & No & Yes & No & Yes & Yes \\
\hline $\begin{array}{l}\text { 3-Lee et al. } \\
{[21]}\end{array}$ & Yes & Yes & Yes & Yes & No & Yes & Yes & No & Yes & Yes \\
\hline $\begin{array}{l}\text { 4-Choi et al. } \\
{[22]}\end{array}$ & Yes & No & Yes & No & No & No & Yes & No & Yes & Yes \\
\hline $\begin{array}{l}5-\text { Shin \& Kim } \\
{[23]}\end{array}$ & Yes & No & Yes & No & No & No & Yes & Yes & Yes & Yes \\
\hline $\begin{array}{l}\text { 6-Keles ef al. } \\
{[24]}\end{array}$ & Yes & Yes & Yes & Yes & Yes & Yes & Yes & No & Yes & Yes \\
\hline $\begin{array}{l}\text { 7-Kwon \& Kim } \\
\text { [25] }\end{array}$ & Yes & No & Yes & Yes & Yes & No & Yes & Yes & Yes & Yes \\
\hline $\begin{array}{l}\text { 8- Kanna \& } \\
\text { Balabaskar [26] }\end{array}$ & Yes & No & No & No & No & No & Yes & No & Yes & Yes \\
\hline
\end{tabular}


Table 4 AACPDM methodological quality and level of evidence

\begin{tabular}{|c|c|c|c|c|c|c|c|c|}
\hline Study & Level of evidence-quality & 1 & 2 & 3 & 4 & 5 & 6 & 7 \\
\hline 1-Rothman [19] & $1-W(3 / 7)$ & No & No & Yes & No & Yes & Yes & No \\
\hline 2-Hutzler et al. [20] & $\mathrm{I}-\mathrm{M}(5 / 7)$ & Yes & Yes & Yes & No & Yes & Yes & No \\
\hline 3-Lee et al .[21] & $\mathrm{I}-\mathrm{M}(5 / 7)$ & Yes & Yes & Yes & Yes & No & Yes & No \\
\hline 4-Choi et al. [22] & $\|-M(5 / 7)$ & Yes & Yes & Yes & No & Yes & Yes & No \\
\hline 5-Shin and Kim [23]. & I-M (4/7) & Yes & Yes & Yes & No & No & Yes & No \\
\hline 6-Keles et al., [24]. & I-S (6/7) & Yes & Yes & Yes & Yes & Yes & Yes & No \\
\hline 7-Kwon and Kim [25] & $\mathrm{I}-\mathrm{M}(5 / 7)$ & Yes & Yes & Yes & No & Yes & Yes & No \\
\hline 8-Kanna and Balabaskar [26] & $\|-M(5 / 7)$ & Yes & Yes & Yes & No & Yes & Yes & No \\
\hline
\end{tabular}

$M$ Moderate, $S$ Strong, $W$ Weak

The AACPDM conduct questions: (a) Were inclusion and exclusion criteria of the study population well described and followed? (b) Was the intervention well described and was there adherence to the intervention assignment? (For 2 group designs, was the control exposure also well described?) Both parts of the question need to be met to score "yes." (c) Were the measures used clearly described, valid, and reliable for measuring the outcomes of interest? (d) Was the outcome assessor unaware of the intervention status of the participants (i.e., were the assessors masked)? (e) Did the authors conduct and report appropriate statistical evaluation including power calculations? Both parts of the question need to be met to score "yes." (f) Were dropout/loss to follow-up reported and less than $20 \%$ ? For 2 group designs, was dropout balanced? (g) Considering the potential within the study design, were appropriate methods for controlling confounding variables and limiting potential biases used?

$=0.45(95 \% \mathrm{CI}$ of mean difference $=0.32,0.58)$. Furthermore, the $95 \%$ confidence intervals of the overall effect estimate did not overlap null effect value, and it is on the right side (favors the study), so the meta-analysis level revealed a significant difference between the study groups and control groups (the overall effect $p$ value is 0.00001 ).

\section{Peak expiratory flow}

Data for meta-analysis could be extracted from six studies [21-26]. As reflected from Fig. 3, the total number of children included into meta-analysis was 88 in the study groups and 87 in control groups. As indicated in Fig. 3, the forest plot of the mean difference across the six studies at $95 \% \mathrm{CI}$ of mean difference is $\mathrm{MD}=0.56(95 \%$ CI of mean difference $=0.22,0.90$ ). Furthermore, the 95\% confidence intervals of the overall effect estimate did not overlap null effect value, and it is on the right side (favors the study), so the meta-analysis level revealed a significant difference between the study groups and control groups (the overall effect $p$ value is 0.001 ).

\section{Forced expiratory volume at $1 \mathrm{~s}$}

Data for meta-analysis could be extracted from six studies [21-26]. As reflected from Fig. 4, the total number of children included into meta-analysis was 88 in study groups and 87 in control groups. The forest plot of the mean difference across the six studies at $95 \% \mathrm{CI}$ of mean difference is $\mathrm{MD}=0.32(95 \% \mathrm{CI}$ of mean difference $=$ $0.14,0.50)$. Furthermore, the $95 \%$ confidence intervals of the overall effect estimate did not overlap null effect value, and it is on the right side (favors the study), so the meta-analysis level revealed a significant difference between the study groups and control groups (the overall effect $p$ value is 0.0005 ).

The heterogeneity tests aim to determine if there are variations among the studies. The $I^{2}$ statistic is presented as a percentage and represents the total variability in the study effect measure which is due to heterogeneity. In the previous three outcomes, the $I^{2}$ value is $<50 \%$, and the test $p$ value is $>0.05$ so the studies can be considered homogenous.

\section{$\mathrm{FEV}_{1} / \mathrm{FVC}$ ratio}

Data for meta-analysis could be extracted from two studies [22, 26]. As reflected in Fig. 5, the total number of children included into meta-analysis was 40 in the study groups and 38 in the control groups. The forest plot of mean difference across both studies at $95 \% \mathrm{CI}$ of mean difference is $\mathrm{MD}=7.77$ (95\% CI of mean difference $=-6.57,22.12)$. Furthermore, the $95 \%$ confidence

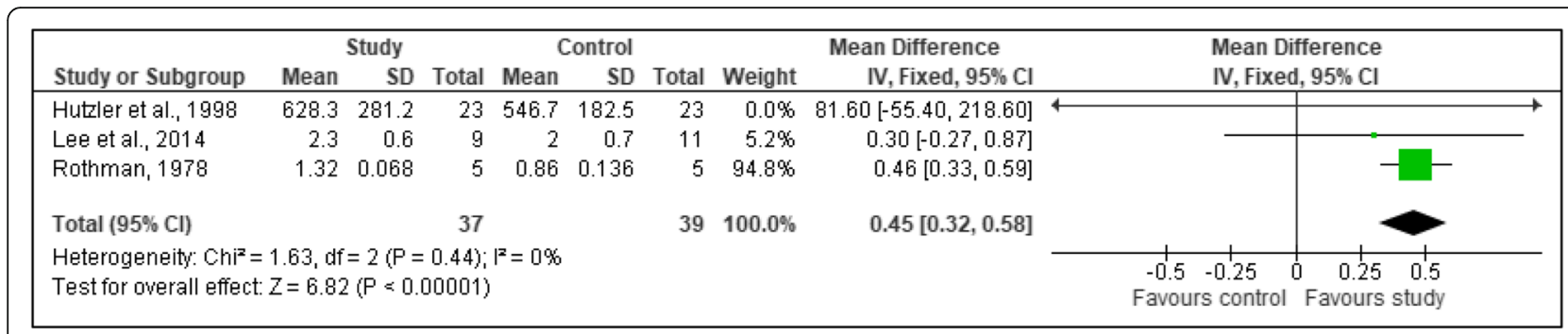

Fig. 2 Forest plot comparison between study and control groups regarding outcome: VC 


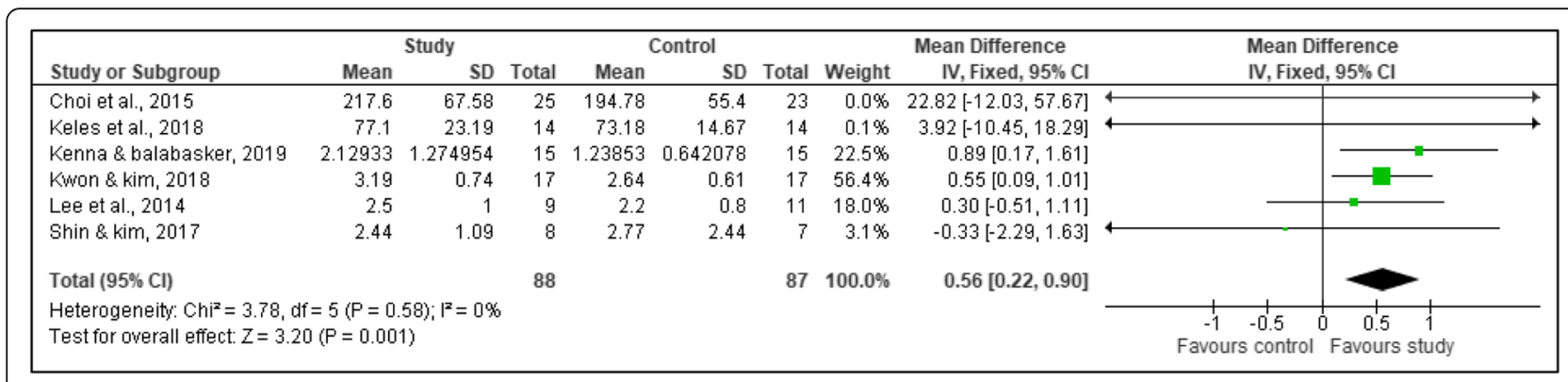

Fig. 3 Forest plot comparison between study and control groups regarding outcome: PEF

intervals of the overall effect estimate overlap null effect value, so the meta-analysis level revealed a non-significant difference between the study groups and control groups (the overall effect $p$ value is 0.29 ). The heterogeneity tests aim to determine if there are variations among both studies. The $I^{2}$ statistic $\left(I^{2}=\right.$ $80 \%, P=0.03$, random-effects model) is presented as a percentage and represents the total variability in the studies' effect measure which is due to heterogeneity. The $I^{2}$ value is $>50 \%$, and the test $p$ value is $<0.05$ which represents high heterogeneity among both studies.

\section{Forced vital capacity}

Data for meta-analysis could be extracted from six studies [21-26]. As reflected from Fig. 6, the total number of children included into meta-analysis was 88 in study groups and 87 in control groups. The forest plot of the mean difference across the six studies at $95 \% \mathrm{CI}$ of mean difference is $\mathrm{MD}=0.39$ ( $95 \% \mathrm{CI}$ of mean difference $=$ $0.02,0.77)$. Furthermore, the $95 \%$ confidence intervals of the overall effect estimate touches the null effect value, and it is on the right side (favors the study), so the meta-analysis level revealed a non-significant difference between the study groups and control groups (the overall effect $p$ value is 0.04 ).

The $I^{2}$ value of the heterogeneity tests of the previous two outcomes is $>50 \%$, and the test $p$ value is $<0.05$ which represents moderate heterogeneity among the studies.

\section{Discussion}

Best practice in rehabilitation requires adequate evidence before an intervention can be considered appropriate in a patient population. The current systematic review aimed to assess the quality and strength of evidence in studies by using systematic methods for searching and evaluating best available studies on the benefit of respiratory therapy for children with $\mathrm{CP}$, based on clinically relevant outcomes including pulmonary functions. Respiration is an important physiologic component for maintaining vital function and performing physical activity in daily life [27]. Respiratory muscle strength in children with $\mathrm{CP}$ is positively correlated with the activities of daily living, self-care, and social function [9].

Respiratory therapy included in this systematic review was divided into: three studies of Lee et al. [21], Keles et al. [24], and Kanna and Balabaskar [26] applied respiratory muscle training, one study of Rothman [19] applied breathing exercises, one study of Choi et al. [22] performed incentive spirometer exercise, and three studies of Hutzler et al. [20], Shin and Kim [23], and Kwon and Kim [25] applied exercise training programs. The number of sessions ranged from 10 to 30 sessions in frequency, and session time ranged from 30 to $45 \mathrm{~min}$. The optimal level of intensity in intervention programs for $\mathrm{CP}$ is still being debated [28].

At this stage it is unclear from the scientific evidence what intensity, duration, or timing of respiratory training is best. The weekly frequency analysis of intervention

\begin{tabular}{|c|c|c|c|c|c|c|c|c|c|c|}
\hline \multirow[b]{2}{*}{ Study or Subgroup } & \multicolumn{3}{|c|}{ study } & \multicolumn{3}{|c|}{ Control } & \multicolumn{3}{|c|}{ Mean Difference } & \multirow{2}{*}{$\begin{array}{l}\text { Mean Difference } \\
\text { IV, Fixed, } 95 \% \text { CI }\end{array}$} \\
\hline & Mean & SD & Total & Mean & SD & Total & Weight & IN, Fixed, 95\% CI & Year & \\
\hline lee etal 2014 & 1.4 & 0.6 & 9 & 1.2 & 0.4 & 11 & $15.6 \%$ & $0.20[-0.26,0.66]$ & 2014 & \\
\hline Choi etal 2015 & 1.57 & 0.44 & 25 & 1.35 & 0.45 & 23 & $51.4 \%$ & $0.22[-0.03,0.47]$ & 2015 & -1 \\
\hline Shin\& kim 2017 & 1.3 & 0.55 & 8 & 1.44 & 0.89 & 7 & $5.6 \%$ & $-0.14[-0.90,0.62]$ & 2017 & 4 \\
\hline Keles etal 2018 & 88.9 & 20.09 & 14 & 94 & 10.35 & 14 & $0.0 \%$ & $-5.10[-16.94,6.74]$ & 2018 & $\longleftarrow$ \\
\hline KWon\& kim 2018 & 2.68 & 0.56 & 17 & 2.01 & 0.88 & 17 & $13.3 \%$ & $0.67[0.17,1.17]$ & 2018 & \\
\hline Kenna \& balabasker 2019 & . 1.28307 & 0.845454 & 15 & 0.59787 & 0.435999 & 15 & $14.1 \%$ & $0.69[0.20,1.17]$ & 2019 & \\
\hline Total $(95 \% \mathrm{Cl})$ & & & 88 & & & 87 & $100.0 \%$ & $0.32[0.14,0.50]$ & & \\
\hline $\begin{array}{l}\text { Heterogeneity: } \mathrm{Chi}^{2}=7.20 \\
\text { Test for owerall effect: } Z=3 \text {. }\end{array}$ & $\begin{array}{l}f=5(P=0 \\
8(P=0.00\end{array}$ & 21); $\left.\right|^{2}=310$ & & & & & & & & $\begin{array}{ccccc}1 & 1 & 1 & 1 \\
-0.5 & -0.25 & 0 & 0.25 & 0.5 \\
\text { Favours [control] } & \text { Favours [study] }\end{array}$ \\
\hline
\end{tabular}

Fig. 4 Forest plot comparison between study and control groups regarding outcome: FEV 


\begin{tabular}{|c|c|c|c|c|c|c|c|c|c|c|c|}
\hline \multirow[b]{2}{*}{ Study or Subgroup } & \multicolumn{3}{|c|}{ Study } & \multicolumn{3}{|c|}{ Control } & \multicolumn{2}{|r|}{ Mean Difference } & \multirow{2}{*}{\multicolumn{2}{|c|}{$\begin{array}{c}\text { Mean Difference } \\
\text { IV, Random, } 95 \% \mathrm{Cl}\end{array}$}} & \\
\hline & Mean & SD & Total & Mean & SD & Total & Weight & IV, Random, $95 \% \mathrm{CI}$ & & & \\
\hline Choi et al., 2015 & 74.48 & 13.98 & 25 & 73.79 & 15.68 & 23 & $51.6 \%$ & $0.69[-7.74,9.12]$ & \multicolumn{2}{|r|}{-1} & \\
\hline Kenna \& balabasker, 2019 & 80.634 & 16.781738 & 15 & 65.302 & 9.991159 & 15 & $48.4 \%$ & $15.33[5.45,25.22]$ & & - & \\
\hline \multicolumn{3}{|l|}{ Total $(95 \% \mathrm{Cl})$} & 40 & & & 38 & $100.0 \%$ & $7.77[-6.57,22.12]$ & & & \\
\hline \multicolumn{5}{|c|}{$\begin{array}{l}\text { Heterogeneity: } \mathrm{Tau}^{2}=85.23 ; \mathrm{Chi}^{2}=4.88, \mathrm{df}=1(\mathrm{P}=0.03) ;\left.\right|^{2}=80 \% \\
\text { Test for owerall effect: } Z=1.06(\mathrm{P}=0.29)\end{array}$} & & & & & -50 & $\begin{array}{ccc}1 & -25 & 1 \\
\text { Favours control } & \text { Favours study }\end{array}$ & 50 \\
\hline
\end{tabular}

Fig. 5 Forest plot comparison between study and control groups regarding outcome: FEV1/FVC ratio

programs used in the studies could not be used to establish a consensus. The data obtained from included studies suggest that in general, a weekly frequency of training greater than or equal to 4 days per week results in significantly improved pulmonary functions. This frequency intervention can be classified as intensive because it is greater than three times per week. Only two studies showed improvements in pulmonary functions with a training frequency less than four. Thus, this finding is in agreement with Tsorlakis et al. [29] who found that therapeutic intervention programs with intensive training achieve significantly higher motor gains than non-intensive training.

A meta-analysis was conducted on all included studies regarding the effect of respiratory therapy on $\mathrm{VC}, \mathrm{PEF}$, $\mathrm{FEV}_{1}, \mathrm{FEV}_{1} / \mathrm{FVC}$ ratio, and FVC. It revealed significant difference between experimental and control groups in $\mathrm{VC}, \mathrm{PEF}$, and $\mathrm{FEV}_{1}$, and non-significant difference in $\mathrm{FEV}_{1} / \mathrm{FVC}$ ratio and $\mathrm{FVC}$ after respiratory training.

Significant improvement in pulmonary functions $\left(\mathrm{VC}, \mathrm{FEV}_{1}, \mathrm{PEF}\right)$ revealed in meta-analysis may be related to increased respiratory muscle strength from training [9]. Previous studies [30, 31] reported that the increase in $\mathrm{VC}$ of the spastic $\mathrm{CP}$ children can be attributed to the better control of breathing through elimination of the abnormal breathing patterns and strengthening of the respiratory muscles. It is possible that the respiratory training is important to counterbalance the natural decline of pulmonary functions in these patients. Rothman [19] recommended performing breathing exercises to children with $\mathrm{CP}$ in order to improve the breathing capacity and decrease the frequency of lung infections. Kim et al. [10] reported that values of pulmonary functions increased after the performance of repetitive actual work using a feedback respiratory training (FRT) device by stroke patients. The increment of FVC was $0.4 \mathrm{~L}$, FEV1 was $0.3 \mathrm{~L}$, and inspiratory reserve volume was $0.2 \mathrm{~L}$. They concluded that feedback respiratory training had a positive effect on the pulmonary function of stroke patients.

Chin and Kim [23] and Keles et al. [24] reported nonsignificant improvement in pulmonary functions in children with $\mathrm{CP}$ who participated in upper extremity resistance training and inspiratory muscle training respectively. These results may be explained by different patient populations or may be caused by different methods of enhancing activity during training interventions and protocols.

Most of included studies had children at gross motor function classification system (GMFCS) levels I-III. According to previous study by Kwon and Lee [32], the children at GMFCS level III had a higher gain in FVC after FRT than the children at GMFCS level I or II. They suggested that children at GMFCS level I or II may have already reached the upper level of their respiratory function capacity so their improvement was not significant after FRT. The normal values of $\mathrm{FVC}$ and $\mathrm{FEV}_{1}$ vary depending on different factors such as height, weight, and sex. In addition, the responses of respiratory training on pulmonary function in children with $\mathrm{CP}$ may differ between unilateral and bilateral CP. Further studies are needed to determine the best candidates for respiratory training.

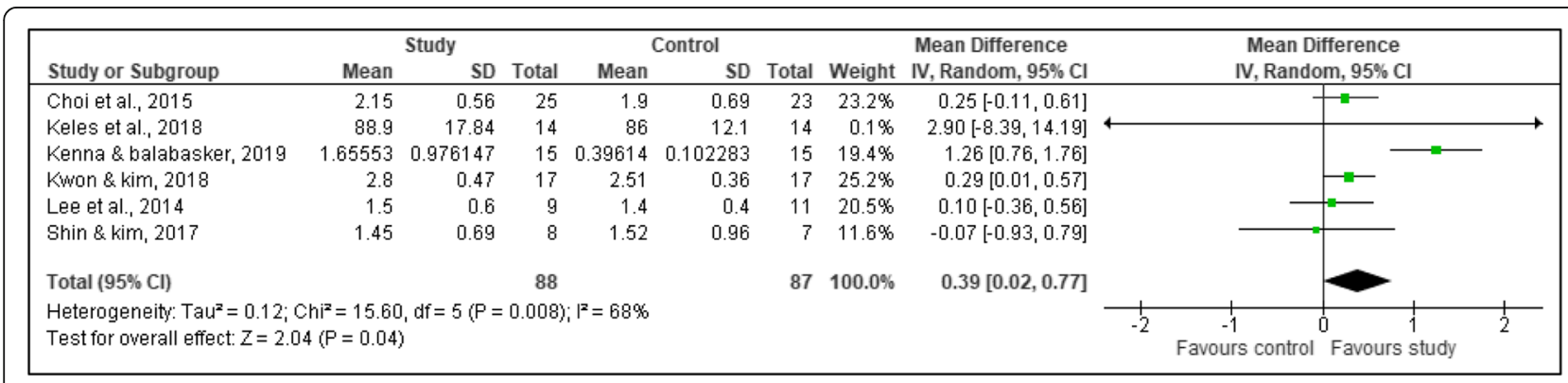

Fig. 6 Forest plot comparison between study and control groups regarding outcome: FVC 
Most studies had participants allocated randomly, had groups of similar baselines, reported results of betweengroups statistical comparisons, and provided measures of variability for at least one outcome. Most of the studies specified the eligibility criteria. In respiratory muscle training, double blind studies are extremely difficult to implement which could be a reason why only two studies $[21,24]$ had concealed allocation and blinded assessors, and three studies $[21,24,25]$ had blinded participant and therapist. All of the included studies obtained at least one outcome from more than $85 \%$ of the initially allocated participants, and only three studies $[19,23,25]$ carried out an intention-to-treat analysis.

Most studies were RCTs. This design enables to estimate the effect of respiratory therapy on children with CP. Randomization reduces bias and provides a comprehensive tool to examine cause-effect relationships between an intervention and outcome which is not possible with any other study design [33]. One study [21] was randomized controlled preliminary report as it had relatively small sample size so its results should be interpreted cautiously.

The limitations of this review include the small number of studies that met inclusion criteria and the variable methodology of these studies (the type, duration, and intensity of respiratory training). The long-term effects after stopping respiratory therapy was not measured; therefore, further research into the various effects should be carried out. Comparison with other respiratory therapy methods and including different outcomes may also be needed. The results of this systematic review need to be interpreted cautiously in the context of small number of available high-quality studies as the effects of respiratory training on pulmonary functions in children with $\mathrm{CP}$ have rarely been reported. Therefore, there is a need for further research to provide adequate evidence to inform clinical recommendations, with adequately powered studies and careful design to minimize bias.

\section{Conclusions}

Meta-analysis supported the efficacy of respiratory therapy on pulmonary functions in children with CP. This systematic review demonstrates an urgent need for welldesigned studies of multiple interventions, not only for management but also prevention of respiratory disease in children with $\mathrm{CP}$, using diverse outcome measures, including activities and participation.

\section{Supplementary Information}

The online version contains supplementary material available at https://doi. org/10.1186/s43161-020-00016-6.

Additional file 1:. Table representing search strategy and its results in different sites

\section{Abbreviations}

AACPDM: American Academy for Cerebral Palsy and Developmental

Medicine; Cl: Confidence interval; CP: Cerebral palsy; FEV ${ }_{1}$ : Forced expiratory volume at 1 s; FEV $25-75 \%$ : Forced expiratory volume between 25 and $75 \%$ of vital capacity; FRC: Functional residual capacity; FRT: Feedback respiratory training; FVC: Forced vital capacity; GMFCS: Gross motor function classification system; MD: Mean difference; PEDro: Physiotherapy Evidence Database; PEF: Peak expiratory flow; PEFR: Peak expiratory flow rate; PRIS MA: Preferred Reporting Items for Systematic Reviews and Meta-analysis; RCT: Randomized controlled trial; TLC: Total lung capacity; VC: Vital capacity

\section{Acknowledgements}

Not applicable

\section{Authors' contributions}

$\mathrm{EH}$ and WM performed an electronic search, data extraction independently, and assessed the methodological quality of included studies where

discrepancies between them were resolved by consultation with the third author El to reach the final decision. The authors read and approved the final manuscript.

\section{Funding}

No source of funding in the current study

Availability of data and materials

All data generated or analyzed during this study are included in the published article.

Ethics approval and consent to participate

Not applicable.

Consent for publication

Not applicable.

Competing interests

The authors declare that they have no competing interests.

Received: 20 March 2020 Accepted: 16 October 2020

Published online: 24 November 2020

\section{References}

1. Rosenbaum P, Paneth N, Leviton A, Goldstein M, Bax M, Damiano D, et al. A report: the definition and classification of cerebral palsy. Dev Med Child Neurol Suppl. 2007;109:8-14.

2. Potharaju NR. Seizures in cerebral palsy. Indian J Cereb Palsy. 2016;2(1):3.

3. D'Angelo MG, Romei M, Lo Mauro A, Marchi E, Gandossini S, Bonato S. Respiratory pattern in an adult population of dystrophic patients. J Neurol Sci. 2011;306(1-2):54-61.

4. Park ES, Park JH, Rha DW, Park Cl, Park CW. Comparison of the ratio of upper to lower chest wall in children with spastic quadriplegic cerebral palsy and normally developed children. Yonsei Med J. 2006;47(2):237-42.

5. Young NL, McCormick AM, Gilbert T, Ayling-Campos A, Burke T, Fehlings D, et al. Reasons for hospital admissions among youth and young adults with cerebral palsy. Arch Phys Med Rehabil. 2011;92(1):46-50.

6. Elema A, Zalmstra TA, Boonstra AM, Narayanan UG, Reinders-Messelink HA, Putten AAJ. Pain and hospital admissions are important factors associated with quality of life in nonambulatory children. Acta Paediatr. 2016;105(9): 419-25.

7. Tomich GM, França DC, Diniz MT, Britto RR, Sampaio RF, Parreira VF. Effects of breathing exercises on breathing pattern and thoracoabdominal motion after gastroplasty. J Bras Pneumol. 2010;36(2):197-204.

8. Wright S, Wakeman R, Collins N, Chatwin M. Physical therapies in pediatric respiratory disease. In: Kendig's disorders of the respiratory tract in children; 2019. p. 273-88. https://www.sciencedirect.com/science/article/pii/ B9780323448871000171.

9. Wang HY, Chen CC, Hsiao SF. Relationships between respiratory muscle strength and daily living function in children with cerebral palsy. Res Dev Disabil. 2012;33(4):1176-82.

10. Kim K, Fell DW, Lee JH. Feedback respiratory training to enhance chest expansion and pulmonary function in chronic stroke: a double-blind, randomized controlled study. J Phys Ther Sci. 2011;23:75-9. 
11. Shapiro DR, Martin JJ. Multidimensional physical self-concept of athletes with physical disabilities. Adapt Phys Activ Q. 2010;27(4):294-307.

12. Boel L, Pernet K, Toussaint M, Ides K, Leemans G, Haan J, et al. Respiratory morbidity in children with cerebral palsy: an overview. Dev Med Child Neurol. 2019;61(6):646-53.

13. Darrah J, Hickman R, O'Donnell M, Vogtle L, Wiart L. AACPDM methodology for developing systematic reviews of treatment interventions (revision 1.2). Milwaukee: American Academy for Cerebral Palsy and Developmental Medicine; 2008. https://www.aacpdm.org/UserFiles/file/systematic-reviewmethodology.pdf.

14. Wiart, et al. Interrater reliability and convergent validity of the American Academy for cerebral palsy and developmental medicine methodology for conducting systematic reviews. DMCN. 2012;54:606-11.

15. DeMorton $\mathrm{N}$. The PEDro scale is a valid measure of the methodological quality of clinical trials: a demographic study. Aust J Physiother. 2009:55:129-33.

16. Teasell R, Hsieh T, Aubut J, Eng J, Krassioukov A, Tu L. Venous thrombo embolism after spinal cord injury. Arch Phys Med Rehabil. 2009;90:232.

17. Sackett D, Strauss S, Richardson W, Rosenberg W, Haynes R. Evidence-based medicine: how to practice and teach EBM. Toronto: Churchill Livingstone; 2000.

18. Moher D, Liberati A, Tetzlaff J, Altman D, The PRISMA Group. Preferred reporting items for systematic reviews and meta-analyses: the PRISMA statement. PLoS Med. 2009;6(7):e1000097. https://doi.org/10.1371/journal. pmed.1000097.g001.

19. Rothman JG. Effects of respiratory exercises on the vital capacity and forced expiratory volume in children with cerebral palsy. Phys Ther. 1978;58(4):421-5.

20. Hutzler Y, Chacham A, Bergman U, Szeinberg A. Effects of a movement and swimming program on vital capacity and water orientation skills of children with cerebral palsy. Dev Med Child Neurol. 1998;40(3):176-81.

21. Lee HY, Cha YJ, Kim K. The effect of feedback respiratory training on pulmonary function of children with cerebral palsy: a randomized controlled preliminary report. Clin Rehabil. 2014;28(10):965-71.

22. Choi JY, Rha DW, Park ES. Change in pulmonary function after incentive spirometer exercise in children with spastic cerebral palsy: a randomized controlled study. Yonsei Med J. 2016;57(3):769-75.

23. Shin SO, Kim NS. Upper extremity resistance exercise with elastic bands for respiratory function in children with cerebral palsy. J Phys Ther Sci. 2017; 29(12):2077-80

24. Keles MN, Elbasan B, Apaydin U, Aribas Z, Bakirtas A, Kokturk N. Effects of inspiratory muscle training in children with cerebral palsy: a randomized controlled trial. Braz J Phys Ther. 2018;22(6):493-501.

25. Kwon HY, Kim BJ. Effects of task-specific movement patterns during resistance exercise on the respiratory functions and thickness of abdominal muscles of children with cerebral palsy: randomized placebo-controlled double-blinded clinical trial. J Phys Ther Sci. 2018:30(8):1073-80.

26. Kanna B, Balabaskar K. A study on efficacy of respiratory exercises coupled with neurodevelopmental treatment on pulmonary function of children with spastic quadriplegic cerebral palsy. Biomed Pharmacol J. 2019;12:1519-24.

27. Buchanan GF. Timing, sleep, and respiration in health and disease. Prog Mol Biol Transl Sci. 2013;119:191-219.

28. Gagliardi C, Maghini C, Germiniasi C, Stefanoni G, Molteni F, Burt DM, et al. The effect of frequency of cerebral palsy treatment: a matched-pair pilot study. Pediatr Neurol. 2008;39(5):335-40.

29. Tsorlakis N. C. Evaggelinou, G. Grouios, C.Tsorbatzoudis. Effect of intensive neurodevelopmental treatment in gross motor function of children with cerebral palsy. Dev Med Child Neurol. 2004;46(11):740-5.

30. Dodd KJ, Taylor NF, Damiano DL. A systematic review of the effectiveness of strength-training programs for people with cerebral palsy. Arch Phys Med Rehabil. 2002;83(8):1157-64.

31. Barks L. Therapeutic positioning, wheelchair seating, and pulmonary function of children with cerebral palsy: a research synthesis. Rehabil Nurs. 2004;29(5):146-53.

32. Kwon YH, Lee HY. Differences of respiratory function according to level of the gross motor function classification system in children with cerebral palsy. J Phys Ther Sci. 2014;26:389-91.

33. Hariton E, Locascio JJ. Randomised controlled trials - the gold standard for effectiveness research: study design: randomised controlled trials. BJOG: Int J Obstet Gynaecol. 2018;125(13):1716.

\section{Publisher's Note}

Springer Nature remains neutral with regard to jurisdictional claims in published maps and institutional affiliations.

\section{Submit your manuscript to a SpringerOpen ${ }^{\circ}$ journal and benefit from:}

- Convenient online submission

- Rigorous peer review

- Open access: articles freely available online

- High visibility within the field

- Retaining the copyright to your article

Submit your next manuscript at $\boldsymbol{\nabla}$ springeropen.com 